\title{
Integrin Beta-4
}

National Cancer Institute

\section{Source}

National Cancer Institute. Integrin Beta-4. NCI Thesaurus. Code C28490.

Integ rin beta-4 (1822 aa, $202 \mathrm{kDa}$ ) is encoded by the human IT GB4 gene. This protein is involved in epithelial cell adhesion. 